\title{
A new combination in Lapanthus (Bromeliaceae)
}

\author{
Rafael Batista Louzada ${ }^{1,2}$, Maria das Graças Lapa Wanderley²
}

I Departamento de Botânica, Instituto de Biociências, Universidade de São Paulo, São Paulo, SP, Brazil 2 Instituto de Botânica, Secretaria do Meio Ambiente, 01061-970, São Paulo, SP, Brazil

Corresponding author: Rafael Batista_Louzada (rafael_louzada@hotmail.com)

Academic editor: L. Versieux | Received 8 July 2012 | Accepted 17 October 2012 | Published 26 October 2012

Citation: Louzada RB, Wanderley MGL (2012) A new combination in Lapanthus (Bromeliaceae). PhytoKeys 17: 6368. doi: $10.3897 /$ phytokeys.17.3642

\begin{abstract}
A new combination, Lapanthus vidaliorum (O.B.C. Ribeiro \& C.C. Paula) Louzada \& Wand. is proposed for Orthophytum vidaliorum O.B.C. Ribeiro \& C.C. Paula. In addition notes on taxonomy, geographic distribution and conservation are provided.
\end{abstract}

\section{Keywords}

Bromelioideae, Cryptanthus, Espinhaço Range, Minas Gerais, Orthophytum

\section{Introduction}

Lapanthus Louzada \& Versieux is a small genus comprising two species occurring in the southern portion of the Espinhaço Range in the Brazilian state of Minas Gerais. The species inhabits quartzitic rocky outcrops near waterfalls and gallery forests in rocky fields or areas of transitional vegetation between semideciduous seasonal forests and rocky fields (Louzada and Versieux 2010).

Lapanthus was established to accommodate two species, one previously included in Orthophytum Beer and the other in Cryptanthus Otto \& A. Dietr. (Louzada and Versieux 2010). The two originally recognized species of Lapanthus (L. duartei (L.B. Sm.) Louzada \& Versieux and L. itambensis (Versieux \& Leme) Louzada \& Versieux) were segregated from Cryptanthus and Orthophytum respectively due to the presence of characters apparently contradictory to the current circumscriptions of those genera, which include ciliate petal margins, presence of a pair of lanceolate petal appendages, and free stamens (Louzada and Versieux 2010). The decision to describe a new genus 
to accommodate the species with these characters was also supported by the evidence of paraphyletism of Orthophytum presented in the molecular phylogeny of Bromelioideae (Schulte et al. 2009). In this study, Orthophytum supthutii E. Gross \& Barthlott, recently synonymized under Lapanthus duartei, arises as the sister group of a clade including Cryptanthus glaziovii Mez, O. disjunctum L.B. Sm. and O. maracasense L.B. Sm.

The phylogenetic relationship of the genus is further elucidated by a study on molecular phylogeny where Lapanthus arises as a monophyletic group, sister to a Cryptanthus clade comprising species of Cryptanthus subgen. Cryptanthus (Louzada et al. in prep.).

The recently described species Orthophytum vidaliorum is morphologically related to O. itambense (=Lapanthus itambensis) and presents the same combination of characters that Louzada and Versieux (2010) used to recognize Lapanthus. Therefore, based on the morphological evidence presented in the protologue and after the analysis of the holotype of $O$. vidaliorum, we propose here a new combination in Lapanthus. This note also provides comments, a table with diagnostic characters (Table 1), photos of the three species, and a distribution map.

Table I. Comparison of some diagnostic characters of Lapanthus, Cryptanthus and Orthophytum.

\begin{tabular}{l|l|l|l}
\hline \multicolumn{1}{c|}{ Character } & Lapanthus & \multicolumn{1}{c}{ Cryptanthus } & \multicolumn{1}{c}{ Orthophytum } \\
\hline Inflorescence & sessile & sessile & pedunculate or sessile \\
\hline Sepals & white & green & green or red \\
\hline Petal margins & ciliate & entire or ciliate & entire \\
\hline Petal appendages type & lanceolate & absent & sacciform, cupuliform or fimbriate \\
\hline Antepetalous stamens & free & adnate, rarely free & adnate \\
\hline Epigynous tube & absent & absent or short & present \\
\hline Meiotic chromosome number & $n=50$ & $n=17$ & $n=25$ \\
\hline Mitotic chromosome number & $2 n=50$ & $2 n=34,36,54$ & $2 n=50,100,150$ \\
\hline
\end{tabular}

\section{Taxonomy}

Lapanthus vidaliorum (O.B.C.Ribeiro \& C.C. Paula) Louzada \& Wand., comb. nov. urn:Isid:ipni.org:names:77122665-1

http://species-id.net/wiki/Lapanthus_vidaliorum

Figs 1, A-B, 2

Basionym: Orthophytum vidaliorum O.B.C. Ribeiro \& C.C. Paula. Brittonia 62: 145, f. 1. 2010. Type: Brazil. Minas Gerais: Santa Bárbara, Serra de Capanema, 20¹1'29"S, 43³5'05.1"W, 1469 m elev., 19 Aug 2008, O.B.C. Ribeiro 208 (holotype: VIC!; isotype: HB).

Notes. When Orthophytum vidaliorum was described, Ribeiro and Paula (2010) discussed its morphological relationship with $O$. itambense. It was emphasized that these species share similar habitat, plant size, leaves, inflorescence and flower structure. Moreover, they state that $O$. vidaliorum is also closely related to $O$. supthutii which was recently synonymized under Lapanthus duartei. In the same article the authors also 

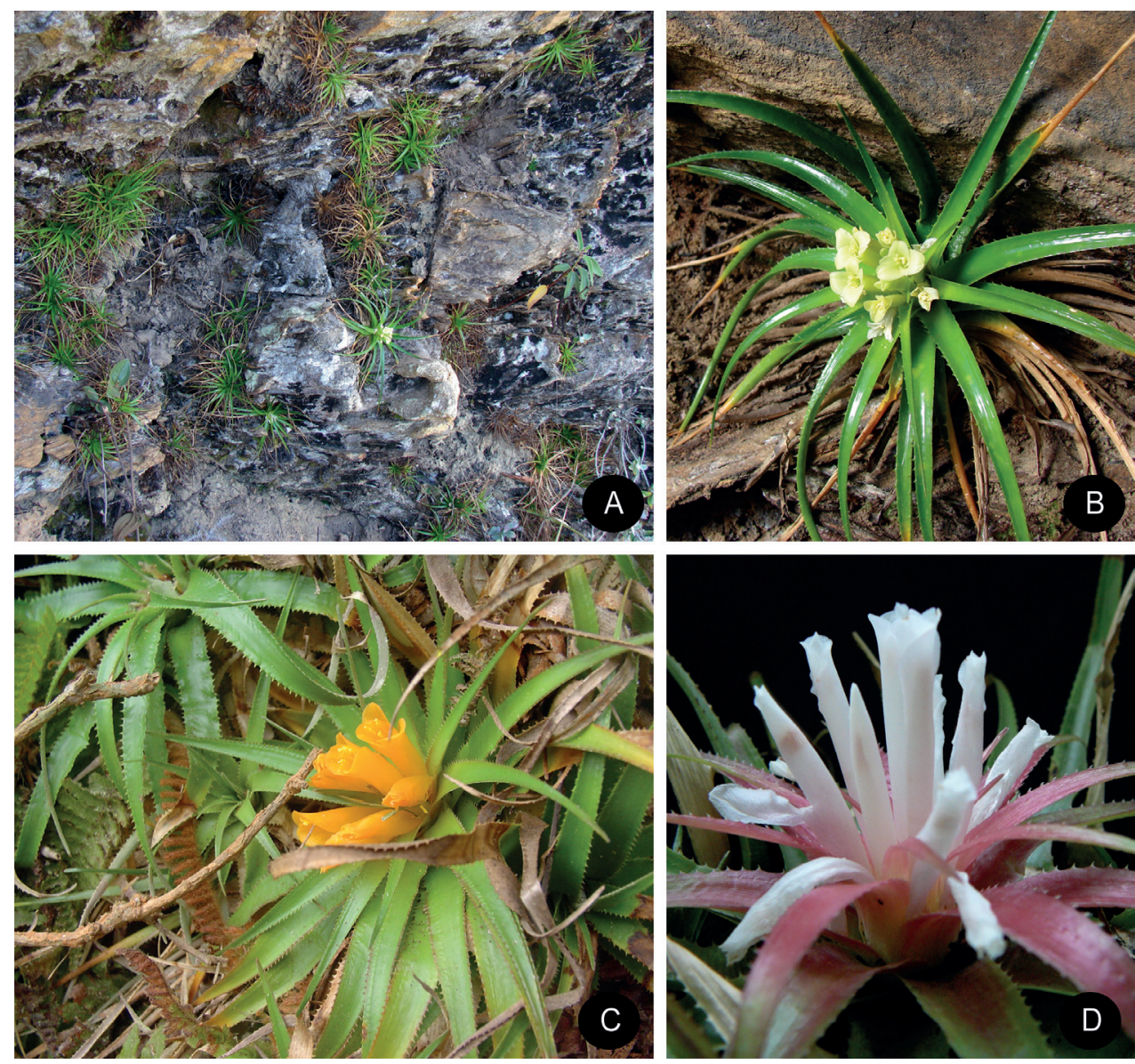

Figure I. A-B. Lapanthus vidaliorum. A Habitat B Habitat in the wild C Lapanthus duartei in the wild D Lapanthus itambensis in cultivation (Photo: A-B Otávio Ribeiro).

mentioned that $O$. vidaliorum could be included in a different and unpublished genus proposed by Louzada (2008) in his master's thesis, which later was validly published under the name Lapanthus by Louzada and Versieux (2010).

Besides, some morphological characters such as the rosette shape, the morphology and size of the leaves and the size of the flowers support the decision to include $O$. vidaliorum under Lapanthus.

Table 2. Comparison of diagnostic characters in Lapanthus species.

\begin{tabular}{c|c|c|c}
\hline Character & Lapanthus vidaliorum & Lapanthus duartei & Lapanthus itambensis \\
\hline Leaf-blade indument & glabrous & lepidote & lepidote \\
\hline Inflorescence branching & simple & compound & pseudo-simple \\
\hline Petal length & $2.5-2.6 \mathrm{~mm}$ & $2.8-3.8 \mathrm{~mm}$ & $4.1 \mathrm{~mm}$ \\
\hline Petal color & greenish-yellow & orange & white \\
\hline Petal appendages & obdeltoid & lanceolate & lanceolate \\
\hline
\end{tabular}




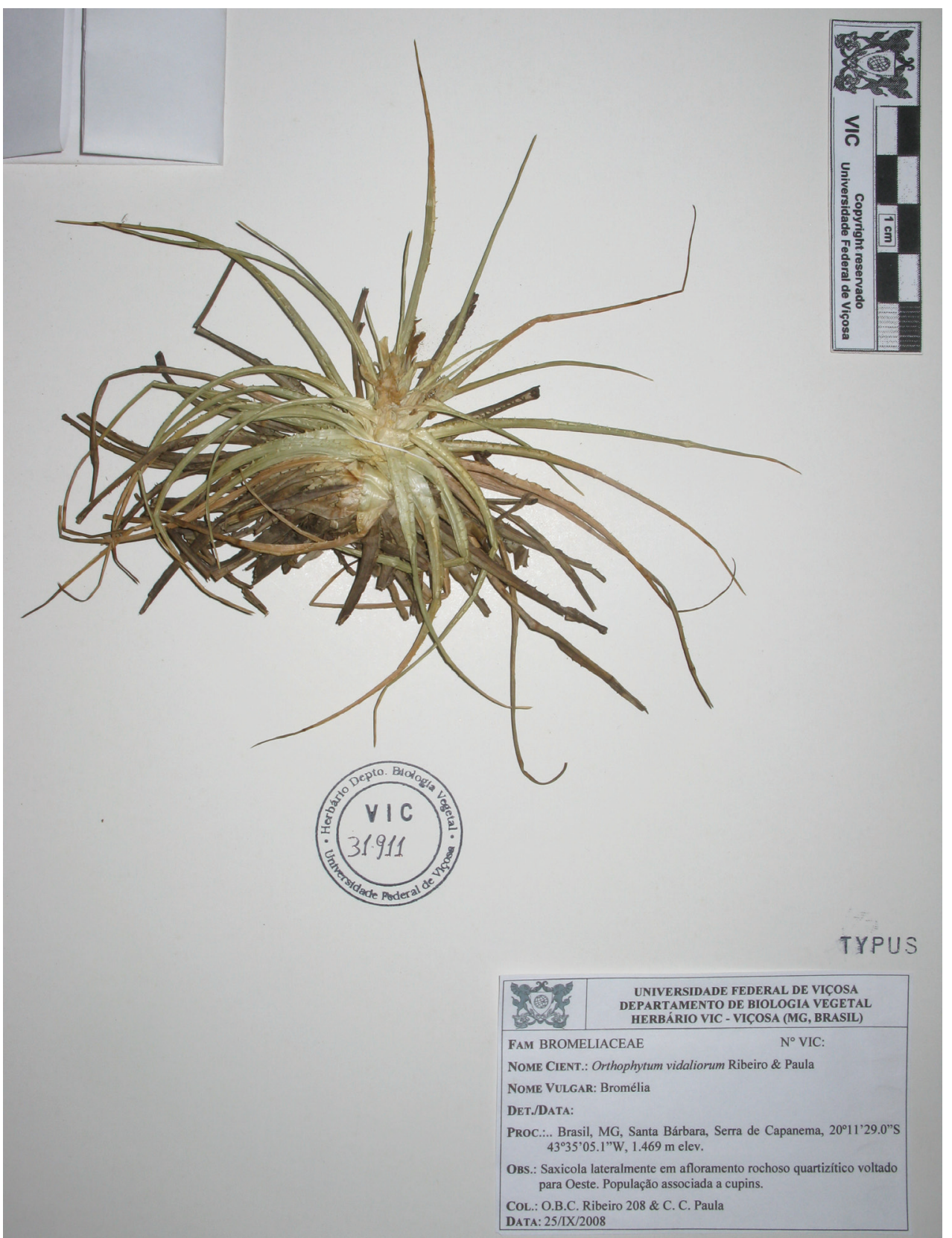

Figure 2. Holotype of Lapanthus vidaliorum (Photo: Elídio Guarçoni).

\section{Identification key for the species of Lapanthus}

1a Inflorescence compound, sepals high connate L. duartei

1b Inflorescence simple or pseudo-simple, sepals free or nearly so 
2a Inflorescence simple, petals greenish-yellow, petal appendages obdeltoid....... L. vidaliorum

2b Inflorescence pseudo-simple, petals white, petal appendages lanceolate

L. itambensis

Distribution. Lapanthus vidaliorum occurs in the southernmost part of the Espinhaço Range, in an iron-rich region called Quadrilátero Ferrífero (Iron Quadrangle) in the Brazilian state of Minas Gerais. Although it occurs in an iron-rich area, L. vidaliorum was found inhabiting quartizitic-sandstone rocky outcrops (Ribeiro and Paula 2010) The present combination extends the genus distribution approximately $120 \mathrm{~km}$ southward (Fig. 3).

Conservation. Lapanthus vidaliorum is an endangered species, known only from the type-population, which is small in number of individuals, being about 3.5 kilometers from the iron ore mine Capanema and surrounded by an Eucalyptus plantation. Therefore, according to IUCN (2001) criteria this species is considered critically endangered (criteria B2a).

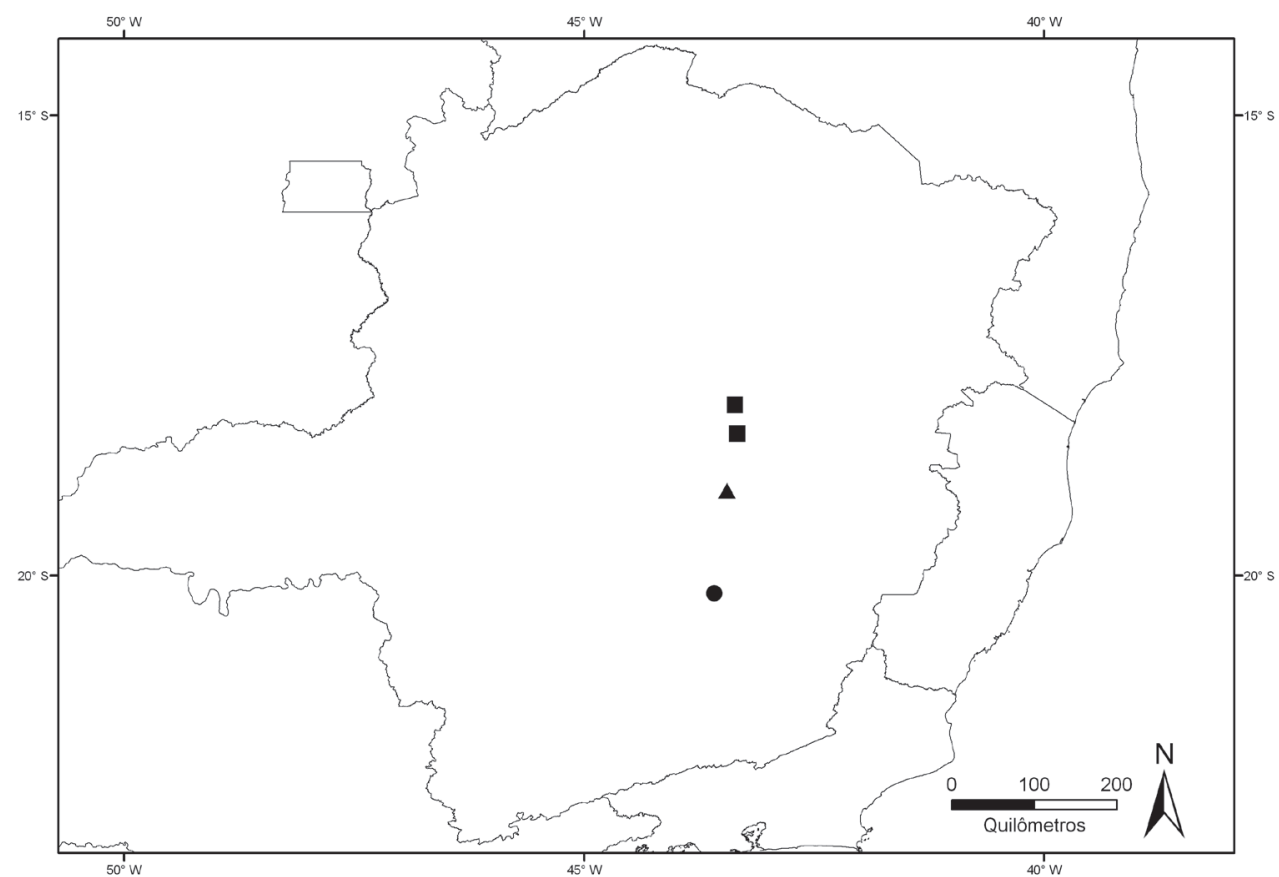

Figure 3. Distribution map of Lapanthus vidaliorum (circle), Lapanthus duartei (triangle), and Lapanthus itambensis (square).

\section{Acknowledgements}

We acknowledge the support from the Brazilian agencies: Fundação de Amparo à Pesquisa (FAPESP) and Conselho Nacional de Desenvolvimento Científico e Tecnológico $(\mathrm{CNPq})$. We thank Tarciso Filgueiras and Derek Butcher for the language 
editing and suggestions to improve the manuscript, Elídio Guarçoni for sending the photo of the holotype and two anonymous reviewers and Leonardo M. Versieux for their comments on the paper.

\section{References}

International Union for Conservation of Nature and Natural Resources - IUCN (2001) IUCN Red List Categories and Criteria, Version 3.1. http://www.iucn.org

Louzada RB (2008) Taxonomia e citogenética das espécies de inflorescência sessile do gênero Orthophytum Beer (Bromeliaceae). Master Thesis, Instituto de Botânica, Brasil.

Louzada RB, Versieux LM (2010) Lapanthus (Bromeliaceae, Bromelioideae): a new genus from the southern Espinhaço Range, Brazil. Systematic Botany 35(3): 497-503. doi: $10.1600 / 036364410792495908$

Ribeiro OBC, Paula CC (2010) A new species of Orthophytum (Bromeliaceae, Bromelioideae) from Minas Gerais, Brazil. Brittonia 62(2): 145-148. doi: 10.1007/s12228-009-9105-9

Schulte K, Barfuss MHJ, Zizka G (2009) Phylogeny of Bromelioideae (Bromeliaceae) inferred from nuclear and plastid DNA loci reveals the evolution of the tank habit within the subfamily. Molecular Phylogenetics and Evolution 51: 327-339. doi: 10.1016/j.ymp ev.2009.02.003 